\title{
Keabsahan Pelaksanaan Harta Bersama Sebagai Implementasi Akad Syirkah
}

\author{
Hubbul Wathan ${ }^{1}$, Indra ${ }^{2}$ \\ ${ }^{1}$ Dosen Politeknik Negeri Medan \\ hbwathan@polmed.ac.id \\ ${ }^{2}$ Dosen STAI Assunnah \\ indra@assunnah.ac.id
}

\begin{abstract}
Abstrak
Artikel ini berisi tentang keabsahan pelaksanaan harta bersama sebagai implementasi akad syirkah. Bila ditelisik, baik Menurut KUHPer, BAB VI Pasal 119, Undang-Undang nomor 1 tahun 1974 maupun KHI Pasal 1 huruf "f". Bahwa harta bersama terjadi saat dilangsungkan perkawinan, sedangkan harta bawaan dari suami dan isteri dan harta benda yang diperoleh masing-masing sebagai hadiah atau warisan, adalah di bawah penguasaan masing-masing sepanjang para pihak tidak menentukan lain. Apakah pelaksanaan harta bersama telah memenuhi kriteria syirkah yang sah?". Karena implikasi dari akad yang tidak sah ialah haram melakukan tindakan hukum yang diakibatkan oleh akad tersebut, atau dalam bahasa awam disebut harta haram. Kebutuhan tersebut semakin mendesak jika menimbulkan konflik dan pihak yang terzalimi secara langsung maupun terdampak, untuk menjawab pertanyaan yang menjadi masalah dalam artikel ini dilakukan analisis terhadap unsur-unsur pokok dalam pelaksanaan harta bersama (subjek hukum, objek hukum, perbuatan hukum, dan akibat hukum dengan pisau analisis yang digunakan adalah kaidah al-'ibratu fil'uqūd bil-maqāṣidi wal-ma'āniy lā bil-alfāzi wal-mabāniy. Temuanya adalah bahwa konsep harta bersama belum sepenuhnya memenuhi kriteria konsep syirkah. Terdapat perbedaan fundamental yang membuat kedua konsep ini seharusnya tidak dapat disamakan. Perbedaan tersebut terdapat pada subjek hukum, perbuatan hukum, dan sifat kedua akad.
\end{abstract}

\section{Kata Kunci : Harta Bersama, Harta Syirkah, Harta Gono gini}

\section{Pendahuluan}

Harta bersama menurut Kamus Besar Bahasa Indonesia ialah harta yang digunakan (dimanfaatkan) bersama-sama. ${ }^{1}$ Tidak ada batasan dengan frasa "oleh suami-istri" untuk adverbia "bersama-sama" dalam pengertian tersebut. Kecuali itu, pada bagian lain terdapat kata harta gana-gini (bentuk baku dari gono-gini) dengan pengertian harta yang berhasil dikumpulkan selama berumah tangga sehingga

${ }^{1}$ Dendi Sugono, (red.) et.al., Kamus Besar Bahasa Indonesia edisi IV (Jakarta: PT. Gramedia Pustaka Utama, 2008), hlm. 512 
menjadi hak berdua suami istri. ${ }^{2}$ Dalam perundang-undangan Indonesia terjadi pergeseran dalam pemaknaan "harta bersama" sebagai istilah hukum. Menurut KUHPer, BAB VI Pasal 119, harta bersama terjadi saat dilangsungkan perkawinan dan meliputi keseluruhan harta suami isteri, sejauh tentang hal itu tidak diadakan ketentuan-ketentuan lain dalam perjanjian perkawinan. ${ }^{3}$ Berikutnya menurut UndangUndang nomor 1 tahun 1974 yang menjadi harta bersama ialah harta benda yang diperoleh selama perkawinan. Adapun harta bawaan dari masing-masing suami dan isteri dan harta benda yang diperoleh masing-masing sebagai hadiah atau warisan, adalah di bawah penguasaan masing-masing sepanjang para pihak tidak menentukan lain. ${ }^{4}$ Harta bersama, kemudian, Dalam Kompilasi Hukum Islam telah diidentifikasi sebagai bentuk syirkah. Pasal 1 huruf "f.” dalam Buku I berbunyi: Harta kekayaan dalam perkawinan atau syirkah adalah harta yang diperoleh baik sendiri-sendiri atau bersama suami-isteri selama dalam ikatan perkawinan berlangsung selanjutnya sisebut harta bersama tanpa mempersoalkan terdaftar atas nama siapapun. ${ }^{5}$

Fikih yang merupakan pengejawantahan aspek hukum Syariat Islam tidak mengenal adanya muștalah harta bersama dalam suatu pernikahan (al-amwāl almusytarakah bayna az-zawjayn). Alquran dan Sunah ecara eksplisit mengatur bahwa nafkah atau biaya hidup rumah tangga adalah tanggung jawab suami. ${ }^{6}$ Isyārah annașs ${ }^{7}$ ayat kewarisan antara suami istri menunjukkan harus ada batasan yang jelas antara harta milik suami dan harta milik istri. ${ }^{8}$ Namun demikian, telah menjadi kebiasan yang luas di berbagai daerah di Indonesia bahwa harta dan nafkah keluarga dihasilkan bersama suami dan istri selama dalam perkawinan, selain harta yang diperoleh masing-masing dari warisan, dari hasil kerja sendiri sebelum mereka menjadi suami istri, dan dari pemberian yang diterima ketika pernikahan. ${ }^{9}$

${ }^{2} I b i d$, hlm. 431.

${ }^{3}$ Saptono Raharjo, ed. 3 Kitab Undang-Undang Hukum: KUHPer KUHP KUHAP Beserta Penjelasannya, (Jakarta: Bhuana Ilmu Populer, cet.2, 2017), hlm. 55.

${ }^{4}$ Undang-Undang nomor 1 tahun 1974 tentang Perkawinan, Pasal 35 ayat 1, 2.

${ }^{5}$ Abdullah, Abdul Gani. Pengantar Kompilasi Hukum Islam dalam Tata Hukum Indonesia, (Jakarta: Gema Insani Pers, 1994), hlm. 77.

${ }^{6}$ Lihat Q.S an-Nisā': 34.

${ }^{7}$ Isyarah nașs ialah makna tersirat yang menjadi suatu kemestian. [lihat: Abdullah Yūsuf al-Juday', Taysìr 'Ilmi Ușūl al-Fiqh, hlm. 313] dalam hal ini ialah bahwa penjelasan tentang bagian suami atas warisan istri dan sebaliknya secara tersirat menghendaki adanya batasan yang jelas tentang harta masing-masing.

${ }^{8}$ Lihat Q.S. an-Nisā’: 12.

${ }^{9}$ Ismuha, Pencaharaian Bersama Suami Isteri di Indonesia: Adat Gono-Gini Ditinjau dari Sudut Hukum Islam, (Jakarta: Penerbit Bulan Bintang, 1978) cet. 2, hlm. 41-43. 
Istri membantu usaha suami menafkahi keluarga atau bekerja secara terpisah menambah pendapatan keluarga merupakan hal yang lumrah dijumpai di tengahtengah masyarakat Indonesia, bahkan bisa jadi penghasilan istri lebih besar dari pada penghasilan suami. Harta yang diperoleh baik sendiri-sendiri atau bersama suami-istri selama dalam ikatan perkawinan berlangsung tersebut memiliki sebutan yang berbeda-beda di berbagai daerah: di Aceh disebut hareuta sihareukat; di Bali dinamakan druwe-gabro, di Jawa barang gana atau gono-gini, di Kalimantang disebut barang-perpantangan, di Madura ghuna-ghana, di Sunda guna-kaya, dan di Sulawesi Selatan dikenal dnegan barang-barang cakkara: ${ }^{10}$ Hukum adat yang terdapat di berbagai daerah inilah kemudian diadopsi oleh KHI. Menurut Ismuha berdasarkan praktek di berbagai daerah di Indonesia, harta bersama dalam pernikahan termasuk syirkah abdān dan mufāwadah. Dikatakan syirkah abdān karena masingmasing suami dan istri sama-sama bekerja membanting tulang untuk mendapatkan nafkah, bekal hari tua, dan warisan untuk anak cucu. Disebut mufāwadah karena perkongsian dalam gono-gini itu bersifat tidak terbatas. ${ }^{11}$

Keabsahan suatu perbuatan menurut syariat, selain telah genap rukunrukunnya juga merujuk kepada tiga hal, yaitu: adanya sebab, terpenuhinnya syarat, dan sunyi dari māni ${ }^{12}$ Kriteria ini juga berlaku pada akad syirkah yang merupakan suatu perbuatan hukum. Dengan demikian pemikiran bahwa harta bersama termasuk implementasi fiqh syirkah dapat dibenarkan jika dalam harta bersama telah terpenuhi rukun, sabab, dan syarat, serta sunyi dari māni` syirkah. Musabab berlakunya harta bersama tidak dengan akad tersendiri tetapi berlaku dengan sendirinya dengan terjadinya pernikahan yang mana objek akadnya bukanlah harta, maka mengemuka suatu pertanyaan, "Apakah pelaksanaan harta bersama telah memenuhi kriteria syirkah yang sah?"

Meneliti dan menemukan jawaban pertanyaan ini dapat dikategorikan sebagai kewajiban pihak yang berkompeten dalam kajian syariah. Musababnya, karena implikasi dari akad yang tidak sah ialah haram melakukan tindakan hukum yang diakibatkan oleh akad tersebut, atau dalam bahasa awam disebut harta haram.

\footnotetext{
${ }^{10}$ Ibid, hlm. 42.

${ }^{11}$ Ismuha, Pencaharian..., hlm. 78-79.

${ }^{12}$ Al-Juday', Taysīr...., hlm. 61;
} 
Kebutuhan tersebut semakin mendesak jika menimbulkan konflik dan pihak yang terzalimi secara langsung maupun terdampak. Allah berfirman,

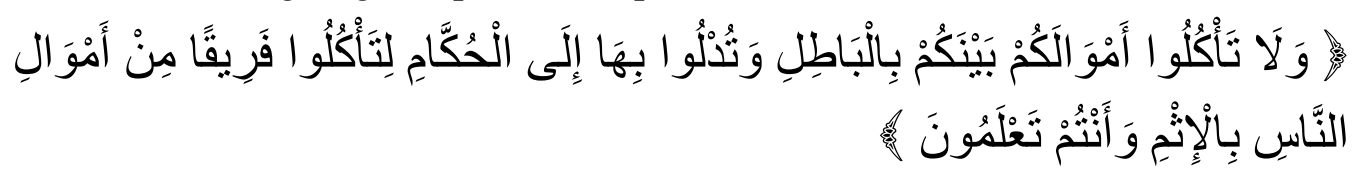

Dan janganlah kamu makan harta di antara kamu dengan jalan yang batil, dan [janganlah] kamu menyuap dengan harta itu kepada hakim, dengan maksud agar kamu dapat memakan sebagian harta orang lain itu dengan jalan dosa, padahal kamu mengetahui. ${ }^{13}$

Rasulullah 能 dalam sejumlah riwayat menyampaikan akibat buruk dan bahaya dari harta yang didapatkan dengan cara yang haram, serta sanksi yang akan diterima pelakunya, seperti: neraka ${ }^{14}$ dan doa yang tidak diterima. ${ }^{15}$

Untuk menjawab pertanyaan yang menjadi masalah dalam makalah ini dilakukan analisis terhadap unsur-unsur pokok dalam pelaksanaan harta bersama (subjek hukum, objek hukum, perbuatan hukum, dan akibat hukum). Apakah unsurunsur tersebut telah memenuhi kriteria unsur-unsur yang membangun syirkah? Pisau analisis yang digunakan adalah kaidah al- 'ibratu fil- 'uqūd bil-maqāṣidi wal-ma 'āniy lā bil-alfāẓi wal-mabāniy.

\section{FIKIH SYIRKAH (SERIKAT)}

\section{Pengertian dan Landasan Hukum}

Syirkah secara kebahasaan berarti ikhtilāt (percampuran). Secara terminologi syirkah, menurut as-Sayyid Sābiq para fukaha mendefinisikan syirkah sebagai akad

${ }^{13}$ Q.S. al-Baqarah: 188; Alquran dan Terjemah, (Depok, Penerbit Sabiq, t.t.), hlm. 29.

${ }^{14}$ Diriwayatkan dari Jābir ibn Abdillah bahwa Rasulullah 敬 bersabda kepada Ka'ab ibn al-'Ujrah, “... Wahai Ka'ab ibn al-'Ujrah, sesungguhnya tidak akan masuk surga daging yang tumbuh dari [harta] yang haram, neraka lebih pantas unutknya!" [lihat: Ahmad ibn Muhammad ibn Ḥanbal ibn Hilāl ibn Asad asy-Syaybāniy, Musnad al-Imām Ahmmad ibn Hanbal, tahkik Syu'ayb al-Arnā'ūṭ dkk, (t.t.p: Mu`assasah ar-Risālah, 1421H/2001M), j. XXII, hlm. 332.

${ }^{15}$ Diriwayatkan dari Abu Hurayrah bahwa Rasulullah 敬 menebutkan perihal seseorang yang melakukan perjalanan jauh; kucel, rambutnya penuh dengan debu, menengadahkan kedua tangannya memohon kepada Allah, "Ya Rabb, Yā Rabb" sementara itu yang dimakannya haram, yang diminumnya haram, yang dipakainya haram, diberi makan dengan yang haram; Bagaimana mungkin doanya akan dikabulkan. [lihat: Muslim ibn alHajjāj ibn Muslim al-Qusyayriy an-Naysābūriy, Al-Jāmi aș-Ṣaḥịh al-Musammā Șahịḥ Muslim, (Beirut: Dār al-Jayl dan Dār al-Afāq, t.t.), j. III, hlm. 85.] 
antara dua orang yang berkongsi dalam pengadaan modal dan perolehan keuntungan yang dihasilkannya. ${ }^{16}$

Dalil keabsahan syirkah ialah Alquran, Sunnah, dan Ijmak. Dalil dari Alquran ialah surah an-Nisā’ayat 12: فهم شركاء في الثلث (mereka berserikat pada yang sepertiga [bagian]), sedangkan Sunnah, di antaranya, ialah hadis qudsi diriwayatkan oleh Abu Hurayrah dari Rasulullah 能,

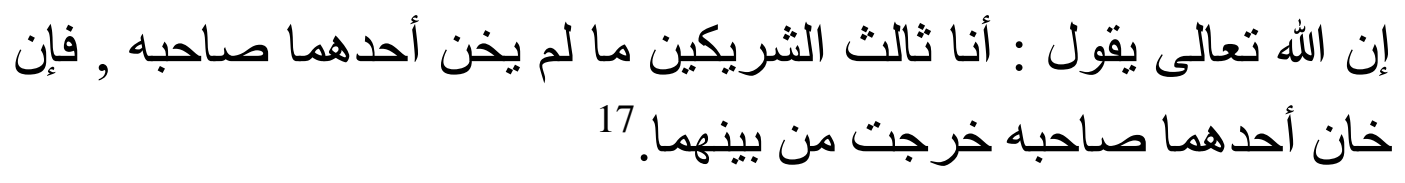

Sesungguhnya Allah berfirman, "Akku adalah Yang Ketiga dari dua orang yang berkongi selagi tidak seorang pun dari keduanya yang mengkhianati rekannya; jika salah seorang mengkhianati rekannya maka Aku keluar dari perkongsian mereka. [H.R. Abu Dawud, ad-Dār al-Quțuniy, al-Hāaim]

Berikutnya para ulama sepaham memaknai bahwa kedua nas ini dan yang semisal menunjukkan legalisasi syirkah dalam syarat Islam. ${ }^{18}$

\section{Macam-Macam Syirkah}

Syirkah berdasarkan sebabnya dibedakan menjadi dua jenis: syirkah al-amlāk (perserikatan kepemilikan), dan syirkah 'uqūd (perserikatan karena akad).

Syirkah al-amlāk ialah kepemilikan yang bersifat ikhtiari atau ijbari oleh sejumlah orang atas benda tertentu tanpa adanya akad tertentu antar para pihak yang berserikat. Yang bersifat ikhtiari seperti hibah suatu benda yang diberikan pihak pertama kepada pihak kedua dan ketiga sekaligus dan pihak kedua dan ketiga bersedia menerima hibah tersebut. Sedangkan yang bersifat ijbāri seperti berserikatnya sejumlah ahli waris atas warisan tertentu. Disebut ijbāri karena terjadinya perserikatan tidak memerlukan persetujuan para pihak yang berserikat.

Syirkah al-'uqūd ialah perserikatan yang terjadi karena dua pihak atau lebih yang berakad untuk berkongsi untuk pengadaan modal usaha dan pemerolehan keuntungan hasil usaha tersebut. Karena syirkah ini terjadi disebabkan adanya akad

\footnotetext{
${ }^{16}$ As-Sayyid Sābiq, Fiqh as-Sunnah, (Kairo: Maktabah Dār at-Turāś, 2005), j. III, hlm. 212.

${ }^{17}$ Abdullah Abdurrahman Șāleh al-Bassām, Tawdị̣̄ al-Aḥkām min Bulūg al-Marām, (Riyāḍ: Dār al-Maymān, 1430H/2009M), j. IV, hlm. 616.

${ }^{18}$ As-Sayyid, Fiqh..., j. III, hlm. 212.
} 
maka rukunnya ialah ijab dan qabul, yaitu: pernyataan ikatan perkongsian dari satu pihak dan pernyataan merima perikatan tersebut dari pihak lain. Syirkah al-'uqūd pada prakteknya dilakukan dalam beberapa bentuk kemudian diberi penamaan sesuai bentuknya itu: syirkah al-'inān, syirkah al-abdān, al-mudāarabah, syirkah al-wujūh, syirkah al-mufāwadah. ${ }^{19}$

a. Syirkah al-'Inān

Syirkah al- 'inān (dibaca juga al- 'anān) ${ }^{20}$ ialah akad antara dua orang atau lebih bahwa masing-masing menyisihkan jumlah tertentu dari harta mereka untuk digabungkan dan dijadikan modal bersama dalam usaha memperoleh keuntungan yang akan dibagi berdasarkan kesepatakan bersama dan sebaliknya jika terjadi kerugian maka ditanggung bersama sesuai persentase dan tanggung jawab masingmasing. Dengan kata lain objek perserikatan dalam syirkah al- 'inān ini ialah harta dan keuntungan yang dihasilkannya. Substansi syirkah al-'inān ini sebatas penggabungan harta untuk mendapatkan keuntungan bersama. Dengan demikian harta yang disisihkan oleh masing-masing pihak untuk digabungkan tidak mesti sama jumlahnya, para pihak yang berserikat pun tidak harus memiliki tanggung jawab dan kewenangan yang sama termasuk pembagian keuntungan. Semua itu kembali kepada kesepakatan di awal.

b. Syirkah al-Abdān

Syirkah al-Abdān ialah akad antara dua orang atau lebih yang bersepakat untuk berkongsi menerima dan melaksanakan suatu pekerjaan tertentu untuk memperoleh keuntungan (upah) bersama yang akan dibagi sesuai dengan persentase yang disepakati bersama. Karena modal utama -yang menjadi objek syirkah -untuk memperoleh keuntungan bukan uang tetapi tenaga dan keahlian yang dimiliki para pihak, syirkah ini juga sering disebut syirkah al-abdān (perserikatan fisik). Para pihak yang berkongsi tidak mesti memiliki keahlian yang sama, tidak mesti melaksanakan volume kerja yang sama, dan tidak mesti bekerja secara bersamaan, bahkan salah satu pihak dapat saja tidak terlibat langsung dalam pekerjaan tetapi ia ikut menyatakan menerima pekerjaan tersebut. Karena itu syirkah ini juga dikenal dengan syirkah attaqabbul.

${ }^{19}$ As-Sayid, al-Fiqh..., j. III, hlm. 212-213.

${ }^{20}$ Al-Mawsū 'ah al-Fiqhiyyah al-Kuwaytiyyah, cet. 2, (Kuwait: Dār as-Salāsil, 1404), j. XXVI, hlm. 36. 


\section{c. Syirkah al-Mudāarabah}

Ulama mazhab Hambali menempatkan mudārabah sebagai bagaian dari syirkah. Musababnya karena mud̄arabah melibatkan dua pihak, substansinya ialah kerja sama berupa perkongsian antara dua belah pihak, pihak pertama menyerahkan harta kepada pihak kedua sebagai modal. Selanjutnya pihak kedua mengerahkan tenaga dan keahlian mengelola modal tersebut dalam suatu usaha untuk memeperoleh keuntungan bersama yang akan dibagi berdasarkan persentase tertentu yang telah disepakati. $^{21}$

\section{d. Syirkah al-Wujūh}

Syirkah al-wujūh (wajah) ialah perkongsian yang dilakukan oleh dua orang atau lebih yang sama-sama tidak memiliki modal tetapi nama baik. Berkat nama baik itu mereka dipercaya oleh para suplayer yang memberikan pasokan barang kepada mereka dengan pembayaran belakangan. Dengan barang-barang yang masih berstatus hutang tersebut mereka menjalankan usaha untuk memperoleh keuntungan bersama yang akan dibagi berdasarkan persentase yang telah disepakati di awal. Syirkah alwujūh ini juga dikenal dengan syirkah al-mafälīs (orang-orang pailit), karena biasanya populer di kalangan orang-orang yang tidak memiliki modal usaha.

\section{e. Syirkah al-Mufāwaḍah}

Secara sederhana mufāwadah berarti saling mendelegasikan. Disebut syirkah al-mufāwaḍh jika para pihak yang berserikat saling menyerahkan semua tanggung jawab dan kewenangan yang dimilikinya atas objek akad syirkah kepada rekan kongsinya. Dengan kata lain para pihak memiliki hak dan kewajiban yang sama terkait objek perserikatan di antara mereka, perbuatan satu pihak menjadi tanggung jawab para pihak lain yang berserikat. Oleh karenanya masing-masing pihak dapat melakukan perbuatan hukum terkait objek perserikatan tanpa persetujuan rekan kongsinya, karena akad semula dipandang telah mewakili. ${ }^{22}$

Terdapat perbedaan pandangan mzahab-mazhab fiqh tentang hukum dan ketentuan syirkah mufāwadah ini. Menurut Imam Syafii hukumnya haram,

\footnotetext{
${ }^{21}$ Abdullah ibn Abdurrahman ibn Abdullah al-Jibrīn, Ibhāāj al-Mu'minīn: bi-syarh
} Minhaj as-Sālikīn wa Tawdịh al-Fiqh fid-Dīn, (Riyāḍ: Dār al-Wațn lin-Nasyr, 1422H/2001), j. II, hlm.

${ }^{22}$ Al-Mawsū'ah ..., j. XXVI, hlm. 39. 
diriwayatkan ia berkomentar, "Jika syarikah mufāwaḍh bukan kebatilan, maka tidak ada kebatilan lain yang saya ketahui!" Sedang ketiga imam mazhab yang lain membolehkan tetapi berbeda pendapat tentang kondisi dan syarat yang harus dipenuhi dalam suatu syirkah al-mufāwaḍh.

Menurut mazhab Hanafi syirkah al-mufāwaḍah dibolehkan jika terdapat kesamaan dalam lima hal:

- Objek syirkah berupa modal. Dalam syirkah al-mufāwadah Para pihak harus menyerahkan modal yang sama besar;

- Perlakuan terhadap objek syirkah. Semua modal dalam syirkah al-mufāwaḍah yang dijadikan sebagai objek perserikatan difungsikan sama. Dalam syirkah al-a'māl maka para pihak sama-sama terlibat dalam penyelesaian pekerjaan dengan cara dan porsi yang sama.

- Keuntungan. Para pihak yang berserikat secara mufāwaḍh memperoleh bagian keuntungan yang sama besar.

- Kewenangan dalam bertindak, para pihak yang berserikat memiliki kecakapan hukum yang sama. Dengan demikian perserikatan tidak sah jika perserikatan yang terjadi antara orang dewasa dengan anak yang belum balig, demikian juga perserikatan orang merdeka dengan budak.

- Tanggungan dan hutang usaha dalam syirkah al-mufāwadah menjadi tanggung jawab bersama secara penuh dan satu sama lain saling menjamin.

Mazhab Maliki tidak mensyaratkan persamaan dalam kelima hal di atas. Menurut mereka mufāwadah cukup dengan tafwīẹ atau pemberian kuasa dari para pihak yang berserikat satu sama lain, karena sebagai pemilik atas harta yang dijadikan sebagai objek syirkah, para pihak berhak penuh melakukan tindakan hukum terhadap hartanya tersebut termasuk menginzinkan pihak lain untuk memanfaatkan atau menguasai miliknya itu sepanjang tidak ada syariat yang dilanggar.

Dalam mazhab Hambali ada dua bentuk syirkah yang diidentifikasi sebagai syirkah mufāwadah. Pertama, sama dengan konsep mufāwaḍh mazhab Hanafi. ${ }^{23}$ Kedua, kombinasi dari semua bentuk syirkah al-amwāl, al-a'māl, al-wujūh dan almud̄ārabah dalam satu syirkah. ${ }^{24}$

\footnotetext{
${ }^{23}$ Al-Mawsū 'ah ..., j. XXVI, hlm. 39.

${ }^{24}$ Abdullah, Ibhāj..., j. II, hlm. 87.
} 
Menurut Șiddīq Hasan Khān nama-nama syirkah -seperti mufāwaḍah, 'inān, wujūh, dan abdān -yang muncul dalam kitab-kitab fikih bukanlah terminologi syariat pun tidak memiliki akar etimologi, melainkan istilah-istilah yang lahir dan berkembang belakangan. Esensinya ialah setiap orang berhak melakukan perbuatan hukum apa saja terhadap harta miliknya sepanjang tidak ada dalil yang mengharamkan perbuatan itu. Demikian juga mewakilkan tanggung jawab dan kewenangan kepada orang lain dengan segala konsekuensinya. Yang dibutuhkan dalam semua itu hanya at-tarạdi (kerelaan kedua belah pihak) semata, sepanjang tidak dalil yang menetapkan syarat-syarat lain termasuk ijab kabul, dan merujuk kepada hukum mana masalah tersebut menginduk. ${ }^{25}$ Pendapat ini memiliki kelemahan karena at-tarạ̣̄ harus memiliki batasan-batasan yang jelas -tidak majhūl sehingga menimbulkan garar dan sengketa di kemudian hari. Fungsi utama akad adalah mengikat para pihak pada batasan-batasan tertentu yang disepakati bersama.

\section{HARTA BERSAMA MENURUT HUKUM POSITIF INDONESIA}

Ketentuan tentang harta bersama dalam hukum Indonesia yang menganut sistem civil law diatur dalam tiga fitur hukum positif: Kitab Undang-Undang Hukum Perdata (KUHPer), Undang-Undang nomor 1 tahun 1974 tentang perkawinan, dan Kompilasi Hukum Islam (KHI).

\section{Pengertian dan Batasan Harta Bersama}

Menurut KUHPer Harta Bersama terjadi dengan sendirinya sejak saat pernikahan dilangsungkan yang meliputi seluruh harta bawaan suami istri sejauh tidak ditetapkan lain dalam Perjanjian Perkawinan. Harta Bersama bersifat mengikat selama perkawinan berjalan tidak boleh ditiadakan atau diubah dengan suatu persetujuan antara suami isteri. ${ }^{26}$ Perjanjian Kawin dibuat dengan akta notaris sebelum pernikahan berlangsung, dan akan menjadi batal bila tidak dibuat secara demikian. ${ }^{27}$ Perjanjian Kawin tidak boleh bertentangan dengan tata susila yang baik,

\footnotetext{
${ }^{25}$ Ṣiddīq Hasan Ali al-Husayniy al-Qanūjiy al-Bukhāriy, ar-Raw ḍah an-Nadiyyah Syarh ad-Durar al-Bahiyyah, (Mesir: Idārah aț-Ṭibā‘ah al-Munīriyyah, t.t.), j. II, hlm. 142-143.

${ }^{26}$ KUHPer, Pasal 119.

${ }^{27}$ KUHPer, Pasal 147.
} 
dan menaati tata tertib umum dan ketentuan-ketentuan perundang-undangan yang berlaku. $^{28}$

Ketentuan tentang batasan dan cakupan Harta Bersama di atas kemudian berubah berdasarkan UU nomor 1 tahun 1974. Dalam UU Perkawinan ini pengertian Harta Bersama dibatasi pada harta benda yang diperoleh selama perkawinan. Dalam Pasal 35 ayat (1) disebutkan, "Harta benda yang diperoleh selama perkawinan, menjadi harta bersama." 29 Sedangkan ayat (2) pasal ini mengatur: "Harta bawaan dan masing-masing suami dan isteri dan harta benda. yang diperoleh masing-masing sebagai hadiah atau warisan, ada di bawah penguasaan masing-masing sepanjang para pihak tidak menentukan lain." ${ }^{30}$ Kompilasi Hukum Islam (KHI) kemudian memperkuat perubahan ini, khususnya bagi umat Islam, dengan penegaskan bahwa pada dasarnya tidak ada percampuran antara harta suami dan harta isteri karena perkawinan, harta isteri tetap menjadi hak isteri dan dikuasi penuh olehnya, demikian juga harta suami tetap menjadi hak suami dan dikuasi penuh olehnya, ${ }^{31}$ baik harta bawaan masing-masing suami dan isteri maupun harta yang diperoleh masing-masing sebagai hadiah atau warisan adalah di bawah penguasaan masing-masing. Meskipun demikian para pihak dapat menentukan lain dalam Perjanjian Perkawinan. ${ }^{32}$ Sama dengan UU Perkawinan, yang menjadi Harta Bersama menurut KHI disebut syirkah, yaitu adalah harta yang diperoleh baik sendiri-sendiri atau bersama suami-isteri selama dalam ikatan perkawinan berlangsung. ${ }^{33}$

\section{Akibat Terjadinya Harta Bersama}

Menurut KUHPer terjadinya Harta Bersama mengakibatkan terjadinya keuntungan dan beban bersama. Termasuk keuntungan bersama ini barang-barang yang diperoleh oleh masing-masing suami isteri secara cuma-cuma-seperti warisan dan hibah -kecuali jika yang mewariskan atau yang menghibahkan dengan tegas menentukan lain. Dan termasuk beban bersama utang yang yang dibuat masingmasing sebelum perkawinan. Sedangkan utang kematian yang terjadi setelah seorang

\footnotetext{
${ }^{28}$ KUHPer, Pasal 139.

${ }^{29}$ UU nomor 1 tahun 1974 tentang Perkawinan, Pasal 35 ayat (1)

${ }^{30}$ Ibid, ayat (2)

${ }^{31}$ Kompilasi Hukum Islam, Pasal 86.

${ }^{32}$ Kompilasi..., Pasal 87.

${ }^{33}$ Kompilasi..., Pasal 1 butir f.
} 
suami ataus istri meninggal dunia tidak termasuk beban bersama, melainkan hanya menjadi beban ahli warisya. ${ }^{34}$

Perubahan batasan Harta Bersama melalui UU nomor tahun 1974 dan KHI dengan sendirinya menyebabkan perubahan pada akibat -keuntungan dan beban yang timbul dari Harta Bersama dimaksud. Berdasarkan batasan Harta Bersama menurut UU nomor 1 tahun 1974 dan KHI tersebut maka keuntungan yang terjadi pada harta masing-masing suami dan istri tidak termasuk ke dalam pertambahan Harta Bersama. Adapun beban-beban, sebagai mana diatur dalam KHI, maka pertanggungjawaban yang dibebankan kepada harta bersama hanya terhadap hutang yang dilakukan untuk kepentingan keluarga. Sedangkan pertanggungjawaban terhadap hutang suami atau isteri dibebankan pada hartanya masing-masing. Bila harta bersama tidak mencukupi, dibebankan kepada harta suami, dan bila harta suami juga tidak ada atau mencukupi dibebankan kepada harta isteri. ${ }^{35}$

\section{Pengelolaan Harta Bersama}

Menurut KUHPer pengurusan Harta Bersama ada pada suami. Dia boleh menjual, memindahtangankan dan membebaninya tanpa bantuan isteri. ${ }^{36}$ Istri hanya boleh mengikatkan atau memindahtangankan harta bersama setelah dikuasakan oleh Pengadilan Negeri, bila si suami tidak ada atau berada dalam keadaan tidak mungkin utuk menyatakan kehendaknya, sedangkan hal ini dibutuhkan segera. ${ }^{37}$ Istri juga dapat memperoleh hak pengurusan Harta Bersama melalui Perjanjian Perkawinan yang dibuat sebelum perkawinan di hadapan notaris. ${ }^{38}$

Ketentuan ini juga mengalami perubahan. Menurut pasal 36 ayat $1 \mathrm{UU}$ Perkawinan suami atau isteri dapat bertindak mengenai harta bersama atas persetujuan kedua belah pihak. Sedangkan KHI mengatur bahwa baik suami maupun istri bertanggung jawab menjaga harta bersama maupun harta pribadi dan harta pasangan masing-masing. ${ }^{39}$ Selain itu KHI juga mengatur harta bersama dapat dijadikan sebagai barang jaminan oleh salah satu pihak atas persetujuan pihak

\footnotetext{
${ }^{34}$ KUHPer, Pasal 123.

${ }^{35}$ KHI, Pasal 93 ayat 2.

${ }^{36}$ KUHPer, Pasal 124.

${ }^{37}$ KUHPer, Pasal 125.

${ }^{38}$ KUHPer, Pasal 140; Pasal 147.

${ }^{39}$ KHI, Pasal 89, 90.
} 
lainnya, ${ }^{40}$ dan bahwa suami atau isteri tanpa persetujuan pihak lain tidak diperbolehkan menjual atau memindahkan harta bersama. ${ }^{41}$ Mafhūm mukhālafah yang terakhir ialah suami atau isteri dengan persetujuan pihak lain diperbolehkan menjual atau memindahkan harta bersama.

\section{Pembubaran Harta Bersama}

Menurut KUHPer Harta Bersama bubar karena: kematian, perkawinan atas izin hakim setelah suami atau isteri tidak ada, perceraian, pisah meja dan ranjang, dan karena pemisahan harta. ${ }^{42}$ Pemisahan harta ialah tuntutan yang diajukan oleh isteri kepada hakim untuk memisahkan harta benda dari harta bersama karena salah satu dari dua sebab: (1) jika suami dengan kelakuan buruk memboroskan harta bersama dan membiarkan rumah tangga terancam bahaya kehancuran; (2) jika suami tidak cakap atau lalai dalam mengurus harta kekayaan sehingga jaminan untuk harta perkawinan isteri serta untuk yang menurut hukum menjadi hak isteri terancam hilang atau dalam keadaan bahaya. ${ }^{43}$ Setelah bubarnya harta bersama, kekayaan bersama mereka dibagi dua antara suami dan isteri, atau antara para ahli waris mereka, tanpa mempersoalkan dari pihak mana asal barang-barang itu. ${ }^{44}$

Aturan pembubaran harta bersama dalam Undang-Undang Perkawinan terbatas pada pasal 37 yang berbunyi "Bila perkawinan putus karena perceraian, harta benda diatur menurut hukumnya masing-masing." Hal ini berkaitan erat dengan aturan bahwa harta dalam perkawinan menurut UU Perkawinan dibedakan menjadi harta masing-masing dan harta bersama. Pasal 38 kemudian menyatakan "perkawinan dapat putus karena: (a) Kematian, (b) Perceraian dan (c) atas keputusan Pengadilan." Karena pembagian harta bersama tidak diatur sedemikian rupa maka dalam hal ini aturan pasal 128 KUHPer tetap berlaku.

KHI juga mengatur pembagian harta bersama apabila terjadi cerai mati (Pasal 96), dan cerai bukan karena kematian (Pasal 97) tetapi substansinya tidak berbeda dengan ketentuan yang diatur dalam KUHPer.

\footnotetext{
${ }^{40}$ KHI, Pasal 91 ayat 4.

${ }^{41}$ KHI, Pasal 92.

${ }^{42}$ KUHPer, Pasal 126.

${ }^{43}$ KUHPer, Pasal 186.

${ }^{44}$ KUHPer, Pasal 128.
} 
Dari uraian di atas dapat ditarik kesimpulan bahwa, berdasarkan hukum positif Indonesia (KUHPer, UU Perkawinan, dan KHI):

- Harta bersama terjadi dengan sendirinya semenjak terjadi perkawinan antara kedua suami isteri.

- Pada asalnya harta bersama ialah harta yang diperoleh suami istri selama perkawinan berlangsung dikurangi beban-beban yang terjadi untuk memenuhi kebutuhan keluarga. Di luar itu harta bersama dapat terjadi melalui perjanjian perkawinan oleh kedua suami istri.

- Kedua belah pihak, suami maupun istri, bertanggung jawab atas keselamatan harta bersama dan berhak melakukan perbuatan hukum atas harta tersebut dengan izin pihak lain.

- Kedua belah pihak, suami maupun istri, berhak melakukan perbuatan hukum terhadap harta tersebut atas persetujuan pihak lain;

- Harta bersama bubar jika perkawinan telah putus baik karena kematian atau perceraian atau dibatalkan oleh pengadilan.

- Ketika terjadi pembubaran harta bersama bagian masing-masing suami istri ialah separo dari harta bersama tersebut.

\section{ANALISIS TERHADAP IMPLEMENTASI SYIRKAH DALAM PELAKSANAAN HARTA BERSAMA}

Untuk menjawab pertanyaan "apakah pelaksanaan harta bersama bagian dari implementasi syirkah” penulis menggunakan kaidah العبرة في العقود بالمقاصد sebagai pisau analisis. Secara luwes, kaidah ini dapat diartikan: hukum suatu akad ditetapkan berdasarkan maksud dan maknanya bukan berdasarkan lafal dan struktur bahasanya. Kaidah ini telah dikenal luas oleh keempat mazhab arus utama dalam fikih Sunni. Tetapi struktur kalimat berita seperti ini hanya dipakai oleh mazhab Hanafi sedangkan mazhab-mazhab lain menggunakan struktur pertanyaan. Dalam mazhab Syafii kaidah tersebut berbunyi: هل العبرة

\footnotetext{
${ }^{45}$ Muslim Muhammad ad-Dawsariy, al-Mumti ' fí al-Qawā 'id al-Fiqhiyyah, (Riyāọ: Dār Zidnī, 1428H/2007M), h. 86.
} 
$46 ?$

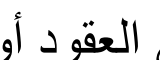
[apakah hukum ditetapkan berdasarkan sigat akad atau maknanya?]. Sedangkan mazhab Hambali menggunakan redaksi إذا وصِل بألفاظ [Jika dihubungkan dengan lafal-lafal akad hal-hal yang mengeluarkannya dari tempatnya semula, apakah akad-akad tersebut menjadi rusak atau tetap jadi?]. Perbedaan struktur kaidah ini, menurut al-Burnū, sebabnya ialah paradigma masing-masing mazhab terhadap validitas kaidah tersebut. Struktur pertanyaan mengindikasikan adanya perbedaan pendapat dalam mazhab tersebut tentang keabsahannya, sedangkan kaidah dengan struktur kalimat positif menunjukkan kesatupandangan mazhab. ${ }^{47}$ Pengidentifikasian harta bersama sebagai implementasi syirkah dalam KHI dapat dikatakan sebagai konfirmasi bahwa paradigma yang dipakai proses penyusunan KHI mazhab yang mengakui keabsahan kaidah ini .

Relevansi kaidah ini terhadap permasalahan yang dibahas ialah adanya upaya penetapan hukum suatu perbuatan yang telah dinamakan dengan istilah tertentu dalam hal ini syirkah -terhadap perbuatan yang dinamakan dengan istilah lain (harta bersama). Berpedoman kepada kaidah ini maka prosedur yang harus dilakukan ialah menguji apakah unsur-unsur substansial yang terdapat pada syirkah juga telah ada dalam pelaksanaan harta bersama? Jika jawabannya positif maka dapat dikatakan bahwa konsep harta bersama merupakan salah satu implementasi syirkah. Jika jawabannya negatif maka harta bersama tidak dapat disamakan dengan syirkah, tetapi tidak tertutup kemungkinan untuk melakukan penyesuaian dengan sejumlah ketentuan tertentu agar semua substansi yang diperlukan terpenuhi.

Berdasarkan uraian dalam sub-bahasan fikih syirkah dipahami, unsur-unsur substansial dalam suatu syirkah meliputi: para pihak yang berserikat (subjek hukum); akad perserikatan (perbuatan hukum); objek perserikatan yaitu: modal usaha -bisa berupa harta, tenaga, atau kredibilitas; -dan akibat hukum (tanggung jawab dan kewenangan, hak dan kewajiban).

\footnotetext{
${ }^{46} \mathrm{Al}$-Burnū, al-Wajīz fĩ Ị̇̂̄ḥ al-Qawā 'id al-Ușūliyyah, (Beirut: Mu`assasah ar-Risalah, 1416H/1992M), hlm. 147.

${ }^{47}$ Ibid, hlm. 29.
} 
1. Kedudukan Suami Istri Sebagai Para Pihak Yang Berserikat

Syirkah setidaknya melibatkan dua pihak yang berakad untuk melakuan perkongsian untuk mendapat keuntungan bersama yang akan dibagi dengan persentase yang disepakati. Berbeda dengan syirkah, perkawinan setidaknya menurut jumhur -melibatkan tiga pihak: suami, istri, dan wali. Meskipun yang akan menjalani kehidupan perkawinan dengan segala untung ruginya adalah suami dan istri tetapi para pihak yang melangsungkan akad adalah suami dan wali [calon] istri. Kedudukan wali dalam pernikahan bukan sebagai wakil [calon] istri tetapi yang menikahkan wanita yang berada dalam perwaliannya dengan laki-laki yang bukan mahram. Dengan demikian berdasarkan subjek hukumnya terdapat perbedaan yang signifikan dan substansial antara syirkah sebagai akad dengan akad nikah.

\section{Kedudukan Akad Nikah Sebagai Akad Syirkah}

Akad nikah tidak dapat disamakan dengan akad syirkah. Perbedaan antara kedua akad tersebut sangat fundamental. Akad nikah, meskipun pengertian yang masyhur berbeda-beda sigatnya antara satu mazhab fikih dengan mazhab fikih yang lain, tetapi semua mengarah pada substansi menghalalkan hubungan badan antara laki-laki dan perempuan yang menjadi suami istri. ${ }^{48}$ Di sisi lain objek syirkah adalah harta kekayaan dan keuntungan yang dihasilkannya. Adapun pemerolehan dan pertambahan kekayaan dalam suatu rumah tangga bukanlah esensi dari pernikahan itu sendiri melainkan wasilah agar kehidupan berumah tangga dapat berlangsung dengan baik. Alhasil akad nikah tidak dapat berfungsi sebagai dan tidak dapat menggantikan akad syirkah.

Menurut Mohd. Idris Ramulyo mengutip Sajuti Thalib dan Hazairin akad nikah dengan sendirinya menyebabkan terjadinya perserikatan. Ia menulis,

Sekali mereka itu terikat dalam perjanjian perkawinan sebagai suami istri maka semuanya menjadi bersatu, baik harta maupun anak-anak, seperti yang diatur oleh Alquran surah IV: 21. Tidak perlu diiringi syir[q]ah, sebab perkawinan dengan ijab qabul serta memenuhi persyaratan lain-lainnya seperti adanya wali, saksi, mahar, walimah, dan i[1]lanun nikah sudah dapat dianggap adanya syir[q]ah antara suami istri itu. Bilamana istri dari seorang suami hamil, kemudian melahirkan anak, sedangkan suami tidak turut mengandung anak yang dikandung istrinya itu dan tidak pula turut serta menderita melahirkan anak tetapi anak tersebut tidak dapat dikatakan anak si istri saja tentulah tidak, sebab anak itu adalah anak dari hasil perkawinan

\footnotetext{
${ }^{48}$ Lihat al-Mawsū'ah al-Fiqhiyyah, j. XLI, hlm. 205.
} 
antara suami istri, bahkan lazimnya lebih ditonjolkakn nama suami atau ayah di belakang nama anak... ${ }^{49}$

Pandangan ini agaknya kurang tepat karena perbedaan fundamental antara akad nikah dan syirkah sebagaimana diterangkan di atas. Kecuali itu, dalil dan argumentasi yang dikemukakan terlihat lemah dan seperti dipaksakan.

Ungkapan “... maka semuanya menjadi bersatu, baik harta maupun anakanak," sedikit berlebihan karena senyatanya tidaklah demikian. Ketika sepasang duda dan janda yang masing-masing memiliki anak menikah, anak-anak mereka tidak lantas, bahkan tidak boleh, berganti orang tua. Undang-Undang Perkawinan pasal 35 ayat 2 sendiri jelas mengatur sebaliknya:

Harta bawaan dari masing-masing suami dan isteri dan harta benda yang diperoleh masing-masing sebagai hadiah atau warisan, adalah di bawah penguasaan masingmasing sepanjang para pihak tidak menentukan lain.

Bahwa pernikahan dalam surah surah an-Nisā' ayat ke-21 disebut mïsāqan galīza atau suatu perjanjian yang suci, kuat dan kokoh $^{50}$ tidak serta merta berimplikasi meleburnya hak-hak kedua belah pihak. Andaikata benar begitu adanya tentu: suami memiliki hak atas mahar yang diterima istri, ${ }^{51}$ Hubungan pernikahan juga tidak lebih kuat dari hubungan nasab, namun demikian masing-masing memiliki hak-hak tersendiri.

Mengkiaskan harta bersama dengan anak hasil perkawinan juga sangat tidak tepat. Anak merupakan hasil pembuahan sel telur istri oleh sel sperma suami, yang dalam bahasa awam disebut darah daging mereka. Sedangkan harta bukan bagian dari diri masing-masing suami-istri, melainkan benda lain yang mungkin diperoleh masing-masing pihak dari pihak lain dengan berbagai cara, dan sebaliknya juga dapat diberikan kepada pihak lain dengan berbagai cara.

Alhasil, agar harta bersama dapat diposisikan sebagai syirkah diperlukan akad tersendiri antara suami dan istri, tidak cukup dengan akad nikah semata (antara calon

${ }^{49}$ Mohd. Idris Ramulyo, Hukum Perkawinan Islam: Suatu Analisis dari Undang-Undang no. 1 Tahun 1974 dan Kompilasi Hukum Islam, (Jakarta: Bumi Aksara, cet. 4, 2002), hlm. 232.

${ }^{50}$ Mohd., Hukum..., hlm. 231.

${ }^{51}$ Ayat tersebut merupakan teguran kepada suami yang mencerai istrinya dan ingin mengambil kembali mahar yang telah diberikannya. Terjemahan ayat tersebut ialah: "Dan bagaimana kamu akan mengambilnya [mahar itu] kembali, padahal kamu telah bergaul satu sama lain (sebagai suami-istri). Dan mereka (istri-istrimu) telah mengambil perjanjian yang kuat dari kamu.” [Q.S. an-Nisā`/04: 21]. 
suami dan wali calon istri). Akad syirkah harta bersama ini seharusnya lebih diperioritaskan dari pada pembacaan sigat $t a{ }^{\prime} l \bar{\imath} q$ talak karena yang pertama berkaitan dengan halal-haramnya harta dan hak-hak pihak lain yang sudah pasti menjadi perkara pada suatu ketika. Tidak demikian halnya dengan sigat $t a ~ ' l i q$ talak yang dapat dikatakan telah kehilangan urgensinya di tengah perkembangan hukum dan kemajuan teknologi seperti saat ini.

Menurut Ismuha ketiadaan sigat ijab kabul (akad) tidak menjadi persoalan. Hal itu, menurutnya, karena pendapat fukahak tentang sigat dalam konteks ini ialah lafal yang memberi pengertian izin pada kongsinya untuk bertindak atas namanya, demikian juga dengan tulisan yang memberi pengertian sama, juga kalalu ada izin serupa itu meskipun tidak ada lafal perkongsian, juga dianggap cukup. Menurut adat kebiasan di Indonesia, dengan terjadinya antara seorang pria dnegan seorang wanita, maka masing-masing pihak sudah memberi izin kepada pihak lainnya untuk bertindak atas namanya dalam menempuh hidup berumah tangga. Maka dalam hal ini berlaku kaidah al-'adah muhakkamah. ${ }^{52}$ Pandangan Ismuha ini tertolak dengan adanya ketentuan yang mewajibkan persetujuan suami atau istri dalam hal salah satu pasangan hendak menjual hak harta mereka, sebagaimana diatur dalam pasal $92 \mathrm{KHI}$,

Suami atau istri tanpa persetujuan pihak lain tidak diperbolehkan menjual atau memindahkan harta bersama.

Ketentuan ini tidak sesuai dengan sifat syirkah mufāwaḍh bahwa masing-masing pihak memberi kuasa seluas-luasnya kepada kongsinya untuk melakukan perbuatan hukum atas objek syirkah tanpa harus merujuk kepadanya, ${ }^{53}$ padahal, menurut Ismuha, harta pencaharian dalam perkawinan termasuk syirkah abdān dan mufāwaḍh. Lebih ketat dari itu mazhab Hanafi bahkan mensyaratkan dalam syirkah mufāwaḍh keseteraan para pihak dalam lima hal: modal, transaksi, tanggungan, keuntungan, dan hak untuk melakukan tindakan hukum. ${ }^{54}$ Alhasil mendudukan harta bersama sebagai syirkah mufāwaḍah adalah fäsidah atau tidak sesuai dengan ketentuan syariat.

\footnotetext{
${ }^{52}$ Ismuha, Pencaharian..., hlm. 109.

${ }^{53}$ Al-Mawsū'ah ..., j. XXVI, hlm. 39.

${ }^{54}$ Ibid.
} 
3. Harta Bersama dan Jenis Syirkah

Undang-Undang Perkawinan pasal 35 ayat 1 mengatur bahwa harta bersama adalah harta benda yang diperoleh selama perkawinan. Dalam ayat berikutnya: Harta bawaan dari masing-masing suami dan isteri dan harta benda yang diperoleh masingmasing sebagai hadiah atau warisan, adalah di bawah penguasaan masing-masing sepanjang para pihak tidak menentukan lain. Ini mengisyaratkan bahwa tidak ada kemestian penggabungan harta sebagai modal. Dengan demikian, harta benda yang diperoleh selama perkawinan dapat diposisikan sebagai keuntungan (upah) yang diperoleh suami-isti dari semua usaha yang mereka lakukan untuk memperoleh penghasilan keluarga. Alhasil, jika harta bersama memenuhi syarat untuk disebut syirkah maka jenis syirkah yang dimaksud adalah syirkah al-abdān.

\section{Hak dan Kewajiban Suami Istri Terhadap Harta Bersama}

Ketentuan pasal 36 UU Perkawinan ayat 1, bahwa mengenai harta bersama, suami atau isteri dapat bertindak atas persetujuan kedua belah pihak, telah sesuai dengan hak dan kewajiban para pihak dalam konsep syirkah, dalam hal ini syirkah alabdān.

\section{Pembubaran Harta Bersama dan Berakhirnya Syirkah}

Pembubaran harta bersama secara tegas diatur dalam KUHPer hanya terjadi jika perkawinan putus. Harta bersama tidak dapat dibubarkan selama perkawinan masih berlangsung. Perjanjian perkawinan hanya dapat meniadakan harta bersama semenjak awal. Dalam UU Perkawinan maupun KHI tidak terlihat aturan yang bertentangan dengan ketentuan ini. Dengan demikian dapat dipahami bahwa harta bersama -jika dapat dikatakan sebagai akad -adalah akad lazim, setidaknya sampai pernikahan putus. Kondisi ini tidak sejelan dengan sifat akad syirkah sebagai akad $j \bar{a} \backslash i z$, yang mana para pihak yang berakad berhak membatalkannya pada waktu yang dikehendakinya. Agar harta bersama dapat dikategorikan sebagai bagian dari implementasi syirkah maka ketentuan ini tentu harus dirubah. 


\section{PENUTUP}

1. Kesimpulan

Berdasarkan uraian yang telah disampaikan dapat kiranya ditarik kesimpulan bahwa konsep harta bersama belum sepenuhnya memenuhi kriteria konsep syirkah. Terdapat perbedaan fundamental yang membuat kedua konsep ini seharusnya tidak dapat disamakan. Perbedaan tersebut terdapat pada subjek hukum, perbuatan hukum, dan sifat kedua akad.

2. Saran dan Masukan

Agar konsep harta bersama dapat didudukkan sebagai salah satu bentuk implementasi syirkah, harus dilakukan perubahan terhadap aturan-aturan yang berhubungan dengan ketiga aspek tersebut.

Hal ini tentu membutuhkan penelitian dan pengkajian yang lebih komprehensif dan mendalam.

\section{DAFTAR PUSTAKA}

Abdullah, Abdul Gani. Pengantar Kompilasi Hukum Islam dalam Tata Hukum Indonesia, Jakarta: Gema Insani Pers, 1994.

Al-Mawsū 'ah al-Fiqhiyyah al-Kuwaytiyyah, cet. 2, Kuwait: Dār as-Salāsil, 1404.

Alquran dan Terjemah, Depok, Penerbit Sabiq, t.t.

Bassām, Abdullah Abdurrahman Șāleh al- Tawḍ̄h al-Aḥkām min Bulūg al-Marām, Riyạ̣̄: Dār al-Maymān, 1430H/2009M.

Bukhāriy, Șiddīq Hasan Ali al-Husayniy al-Qanūjiy al-. ar-Rawḍh an-Nadiyyah Syarh ad-Durar al-Bahiyyah, Mesir: Idārah aț-Ṭibā'ah al-Munīriyyah, t.t., j. II, hlm. 142-143.

Burnū, Muhammad Șidqiy Al-. al-Wajīz fì Ị̇̂ạh al-Qawā'id al-Ușūliyyah, Beirut: Mu`assasah ar-Risalah, 1416H/1992M.

Dawsariy, Muslim Muhammad ad-. al-Mumti ' fì al-Qawā'id al-Fiqhiyyah, Riyāḍ: Dār Zidnī, 1428H/2007M.

Ismuha. Pencaharaian Bersama Suami Isteri di Indonesia: Adat Gono-Gini Ditinjau dari Sudut Hukum Islam, Jakarta: Penerbit Bulan Bintang, 1978. cet. 2

Jibrīn, Abdullah ibn Abdurrahman ibn Abdullah al-. Ibhāāj al-Mu 'minīn: bi-syarh Minhaj as-Sālikīn wa Tawọ̄ḥ al-Fiqh fid-Dīn, Riyāḍ: Dār al-Waṭn linNasyr, 1422H/2001. 
Naysābūriy, Muslim ibn al-Ḥajjāj ibn Muslim al-Qusyayriy an-. Al-Jāmi ‘ aṣ-Ṣaḥịh alMusammā Ṣaḥ̄ḥ Muslim, Beirut: Dār al-Jayl dan Dār al-Afāq, t.t.

Raharjo, Saptono. ed. 3 Kitab Undang-Undang Hukum: KUHPer KUHP KUHAP Beserta Penjelasannya, Jakarta: Bhuana Ilmu Populer, cet.2, 2017.

Ramulyo,Mohd. Idris. Hukum Perkawinan Islam: Suatu Analisis dari UndangUndang no. 1 Tahun 1974 dan Kompilasi Hukum Islam, Jakarta: Bumi Aksara, cet. 4, 2002.

Sābiq, As-Sayyid. Fiqh as-Sunnah, Kairo: Maktabah Dār at-Turās̀, 2005.

Sugono, Dendi (red.) et.al., Kamus Besar Bahasa Indonesia edisi IV, Jakarta: PT. Gramedia Pustaka Utama, 2008.

Syaybāniy, Ahmad ibn Muhammad ibn Ḥanbal ibn Hilāl ibn Asad asy-. Musnad alImām Ahmmad ibn Hanbal, tahkik Syu'ayb al-Arnā'ūt dkk, (t.t.p: Mu`assasah ar-Risālah, 1421H/2001M.

Undang-Undang nomor 1 tahun 1974 tentang Perkawinan. 